\title{
Benchmarking energy use in the paper industry: a benchmarking study on process unit level
}

\author{
Jobien Laurijssen • André Faaij • Ernst Worrell
}

Received: 15 November 2011 / Accepted: 21 June 2012 / Published online: 13 July 2012

(C) The Author(s) 2012. This article is published with open access at Springerlink.com

\begin{abstract}
There are large differences between paper mills in, e.g. feedstock use and grades produced, but typical processes are similar in all mills. The aim of this study is to benchmark the specific energy consumption (SEC) of similar processes within different paper mills in order to identify energy improvement potentials at process level. We have defined improvement potentials as measures that can be taken at mill/ process level under assumed fixed inputs and outputs. We were able to use industrial data on detailed process level, and we conducted energy benchmarking comparisons in 23 Dutch paper mills. We calculated average SECs per process step for different paper grades, and we were able to identify ranges in SECs between mills producing the same grade. We found significant opportunities for energy efficiency improvement in the wire and press section as well as in the drying section. The total energy improvement potential based on identified best practices in these sections was estimated at $5.4 \mathrm{PJ}$ (or $15 \%$ of the total primary energy use in the selected mills). Energy use in the other processes was
\end{abstract}

J. Laurijssen $(\bowtie)$

Centre of Competence Paper and Board, IJsselburcht 3, 6825 BS Arnhem, The Netherlands e-mail: J.Laurijssen@kcpk.nl

A. Faaij · E. Worrell

Copernicus Institute, Utrecht University,

Van Unnikgebouw, Heidelberglaan 2,

3584 CS Utrecht, The Netherlands found to be too dependent on quality and product specifications to be able to quantify improvement potentials. Our results emphasise that even a benchmark on detailed process level does not lead to clear estimations of energy improvement potentials without accounting for structural effects and without having a decent understanding of the process.

Keywords Benchmark · Paper industry · Energy efficiency

\section{Introduction}

The production of paper and board is an energy intensive process. With an energy use of $6.4 \mathrm{EJ}$ in 2005 , the pulp and paper industry was responsible for about $6 \%$ of the world's total industrial energy consumption (International Energy Agency (IEA) 2008), being the fourth largest industrial energy user worldwide. Energy prices rose drastically from 2005 until 2008 by around $40 \%$ on average in Europe (Confederation of European Paper Industries (CEPI) 2007). Even though energy prices declined in 2009, they are still one of the major cost components of the pulp and paper sector today. Energy accounted for $19 \%$ of the total operating costs of the European pulp and paper industry in 2005, compared with $15 \%$ in 2001 (Confederation of European Paper Industries (CEPI) 2007). For selected mills, the 2008 share of energy in production costs was up to $30 \%$ (Confederation of 
European Paper Industries (CEPI) 2008). Most of the pulp and paper mills have become part of the Emission Trading System and the industry's vision is to further improve its performance in terms of greenhouse gas emissions (Confederation of European Paper Industries (CEPI) 2008) and energy efficiency.

\section{Defining energy improvement potentials}

Energy consumption in an industrial sector is determined by the activity level, sector structure and energy efficiency (Phylipsen et al. 1997). In order to identify the potential to reduce energy consumption, it is important to differentiate energy efficiency effects from other effects. Phylipsen et al. 1997 describe an approach to separate structural effects from efficiency effects in international comparisons of industrial sectors. According to them, the sector structure can be defined as being determined by the mix of activities or products within a sector. The choice for a definition based on "mix of activities" or "mix of products" can in some cases make a significant difference in determining what can be considered an energy efficiency effect or a structural effect. If the mix of products is used as a definition of structure, printing paper produced from virgin fibres and printing paper produced from recycled fibres can be considered two different processes to produce the same product. The switch from virgin to recycled fibres could in this approach be seen as an energy efficiency measure. Defining structure as the mix of processes, one might argue that the two process routes are different activities and differences in energy consumption between the two are then to be considered structural effects.

Benchmarking at different levels of aggregation

In order to estimate industrial energy improvement potentials, energy benchmarks can be used. Energy benchmarks can be applied at different levels of aggregation (e.g. sector, country, mill or process levels), depending on the typical goal of the benchmarking exercise. The extent to which structural differences influence the energy improvement potential also depends on the aggregation level (Phylipsen et al. 1997). On country level, an energy efficiency improvement potential could for example be found in the substitution of plastic by paper. Whereas this is not a measure that can be taken at the individual mill or process level.
Energy efficiency indicators

Energy efficiency is defined as the amount of human activity provided per unit of energy used. In practice, indicators often measure the inverse of energy efficiency (Phylipsen et al. 1997). A frequently used quantitative indicator at a high level of aggregation is energy intensity, which measures activity in economic terms (e.g. Freeman et al. 1997; Eichhammer and Mannsbart 1997; Farla and Blok 2000; Ramirez et al. 2005; Neelis et al. 2007; Tanaka 2008). At a lower level of aggregation, an often used indicator is specific energy consumption (SEC), which reflects the amount of energy required to produce one physical unit of product (e.g. tons of product) (e.g. Worrell et al. 1994; Patterson 1998; Rafiqul et al. 2005; Salta et al. 2009). SEC is mostly determined at country/sector level (e.g. Farla and Blok 2000; Neelis et al. 2007) or at product level (Farla et al. 1997; De Beer et al. 1997). A specification into feedstock use and product quality is seldom made (Lazarus et al. 1999; Ruth et al. 2001).

Energy efficiency at process level in the paper industry

In the first Reference Document of the European Commission on Best Available Techniques in the Pulp and Paper Industry (BAT/BREF) (European Integrated Pollution Prevention and Control Bureau (EIPPCB) 2001) some (best practice) figures on energy demands of different process units for different pulp and paper types are documented. Although many processes are taken into account, a drawback of the report is that data come from a variety of sources and calculation methods are not always identified. Worrell et al. (1994) calculate the SEC of different industrial sectors by adding the individual SECs of different industrial activities within a sector. They define SECs for processes with a well-described input (feedstock) and output (product) and aggregate these to calculate the SEC of an industrial sector in a country. With regard to the paper industry, they included SECs of three pulp types and five paper grades. Different processes within paper production are not explicitly taken into account. The same is valid for a study by Francis et al. (2006) who collected energy consumption and production data for processes in 49 pulp and paper mills. The processes chosen in this study are mainly pulping processes, whereas the papermaking 
process is considered as a whole. Manufacturing of paper is however not a single process but a series of unit processes, often linked and interdependent. Although there are large differences between different paper mills, using different types of feedstock and producing different paper grades (and qualities), the typical processes involved in paper production could be broken down in a number of activities that are similar in all mills.

\section{Aim and outline}

The aim of this study is to benchmark the SEC of similar processes within different paper mills in order to identify energy improvement potentials at process level. We define improvement potentials as measures that could be taken at mill/process level under assumed fixed inputs and outputs. If we compare this with the approach described in Phylipsen et al. (1997), we define structure as a mix of activities, but we also take into account the product mix. We first describe the papermaking process in general. Then, the data collection methodology is explained. Next, the results are presented in a benchmarking study on process unit level and energy improvement options at process level are identified when possible and/or relevant. This is followed by a discussion of the results. Conclusions are drawn in the final section.

\section{General process description of papermaking}

In Fig. 1, a schematic overview of different processes in paper production is shown. Paper is made from pulp, which can be produced from wood fibres (via mechanical pulping or chemical pulping), from recovered paper or in particular cases from non-wood fibres $^{1}$ (e.g. straw, jute and synthetic). Since we focus on the papermaking processes only, we exclude the pulping processes and assume that fibres are already disclosed. Raw materials included are virgin pulp and recovered paper.

Before pulp enters the paper machine, some treatment steps may be necessary. Stock preparation consists of several processes (e.g. fibre disintegration, cleaning, fibre modification and storage and mixing steps) that are adapted to one another. These systems

\footnotetext{
${ }^{1}$ The use of non-wood fibres is outside the scope of this paper.
}

differ considerably depending on the raw stock used and on the quality of furnish required (European Integrated Pollution Prevention and Control Bureau (EIPPCB) 2001). Pulp from recovered fibres needs to be cleaned in several cleaning steps to remove impurities, e.g. staples, plastics and glue. Sometimes, this type of pulp is also de-inked, depending on product specifications. Ink removal is necessary in plants manufacturing paper grades where brightness and cleanliness is important, e.g. for newsprint, tissue or light topliner of recovered paper-based carton boards. Another process step that is sometimes applied in stock preparation of recovered fibres is dispersion. During this step, impurities that could not be removed are reduced to a size small enough not to harm paper quality. Dispersion can be performed after de-inking in order to achieve improved fibre-to-fibre bonding (better strength characteristics) in the paper produced and to reduce visible dirty specks in size (European Integrated Pollution Prevention and Control Bureau (EIPPCB) 2001). Before dispersion, the dry solids content of the pulp has to be increased from around 5-12 to $25-30 \%$ because dispersion requires strong friction forces and high temperatures at around $95{ }^{\circ} \mathrm{C}$ or more (European Integrated Pollution Prevention and Control Bureau (EIPPCB) 2001). Paper grades produced from virgin fibres sometimes require a refining step, where fibres are beaten to roughen their surface in order to enhance fibre properties. Refining is carried out in refiners equipped with, e.g. a rotating disk that is pressed on a stator. The order of the operation of stock preparation may vary from mill to mill and some of the steps may be repeatedly performed. Finally, pulp is stored and blended.

After pulp has undergone all necessary process steps in stock preparation, it is spread on a screen in the former/wire section. In this section, a large share of water is removed by gravitational forces and a vacuum. In the former/wire section, the dry matter content of the paper web increases from about $1 \%$ to approximately $20-25 \%$. In the press section, the dry matter content of the paper web is further increased to about $50 \%$ by means of press cylinders. Although some thermal energy is used in the press section, most of the dewatering takes place via mechanical work. Thermal dewatering (drying section) requires more energy per removed ton of water than mechanical dewatering and it is therefore beneficial to remove as much water as possible in the press section. After 
Stock preparation

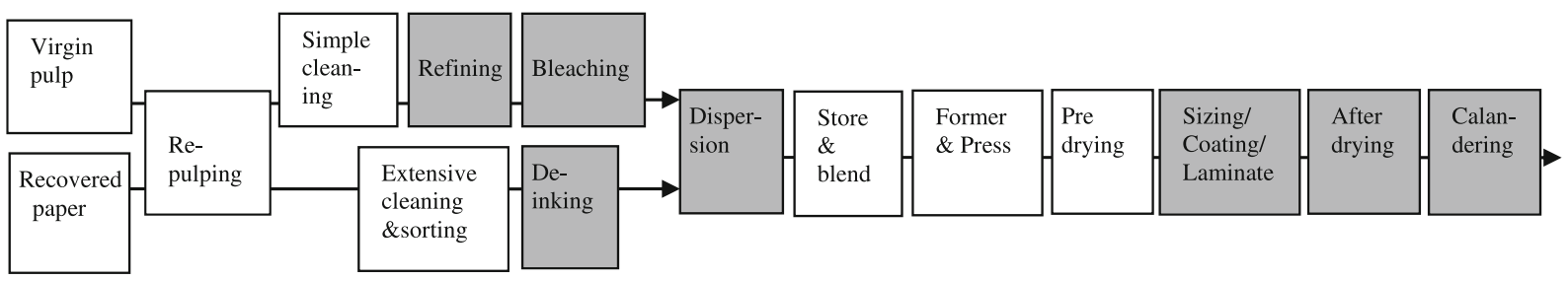

Optional process steps

Fig. 1 Schematic overview of different process steps in paper production

the former section, the paper web enters the press section where further water is removed mechanically. Remaining water is removed thermally in the drying section. In the drying section, the dry matter content of the paper web increases from approximately 50 to around $95 \%$. In many paper and board mills, the drying section is divided into a pre-drying and an after-drying section (Fig. 1). In between these sections, there is often a size press or coating machine for surface property adaptations. In some board mills, this section is used for gluing of additional surface papers. Since these processes add additional moisture to the paper or board, an after drying section is needed to remove the added water.

\section{Methodology}

The Dutch paper industry is for approximately $80 \%$ recovered paper based (VNP 2010). Dutch paper mills that are virgin fibre based, purchase pulp on the market while two produce thermo-mechanical pulp (TMP). In several cases, there is a mixture of raw materials. The Dutch paper and board industry produces a great variety of products. Products range from newsprint, corrugated board, solid board, printing papers and tissue to various types of specialty papers (VNP 2010).

Data used for this study

To monitor the energy housekeeping of Dutch paper and board mills, The Royal Netherlands' Paper and Board Association (VNP) together with Gasunie/MPI have developed a product/energy management system (MPI-PEMS). MPI-PEMS has been implemented in all paper and board mills in The Netherlands. The system is used for annual monitoring of energy efficiency developments in the industry and several mills use it to manage energy within the mill. In this study, we use data from the MPI-PEMS model to develop a benchmarking study for the Dutch paper/board industry on process unit level. The MPI-PEMS system is based on a product and an energy balance. For each process operation, the incoming and outgoing materials (e.g. intermediate products and process wastes) are determined, together with the dry matter content of the flows. Energy consumption (heat, electricity and fuel) of each individual process unit is measured. As both production and energy consumption data are available, it is possible to generate SEC figures on process level. The total amount of gas and electricity use is reported as well as the efficiencies of their energy conversion installation. Also, data on electricity, heat and gas use per process operation are measured and reported. Material flows are reported starting from the fibre raw material input, additions of additives and ending with the amount of saleable product produced. Process waste is reported per unit operation and in total. Dry matter content of the paper web is reported before and after the wire, after the press, in between the drying sections. Data are mills' annual totals and are not specified per product produced within the mill.

The raw data are confidential and of a very high quality. Data are provided by the paper mills themselves. Although each mill has used its own measuring devices, the process of data collection has been guided by a single expert for all mills and a uniform format for data management was used by all mills. The same system and process boundaries were therefore used throughout the sector. More than 200 data points were 
provided by every single mill, which makes this industrial data collection effort unique in itself.

System boundaries

In the year 2005, 25 paper and board mills were in operation in The Netherlands. In this report, we will report (2005) data for 23 mills. Two mills have very specific production processes and for reasons of confidentiality and lack of representativeness, energy figures from these two mills are excluded from the analysis. For the purpose of this study, we present aggregated (electricity, heat and fuel) energy data for the SEC of the following processes:

- De-inking

- Dispersion

- Stock preparation

- Forming and press section

- Pre-dryer section

- After dryer section

Often when energy consumption in the paper industry is analysed, only the main equipment is included whereas, e.g. pumps, agitators and peripheral subsystems for water are not part of the system considered. These processes do not improve pulp or paper quality but are nevertheless relevant in terms of electricity demand. The contribution of pumps and agitators to the total installed power may even vary from 20 up to $30 \%$ (European Integrated Pollution Prevention and Control Bureau (EIPPCB) 2001). In this study, the energy use of, e.g. pumps is included as long as it can be contributed directly to a specific process. There is a difference between installed power (main equipment) and average power demand that is actually used. In this study, we have used actual energy consumption figures. The energy use related to site utilities (e.g. water treatment plant, own energy use of boiler house etc.) has been excluded in this study.

Heat recovery is a common feature in paper mills. In 2005, only internal heat recovery was established in Dutch paper mills; no heat was sold to external parties. In our approach, the effects of internal heat recovery are not explicitly taken into account, but they implicitly lead to a reduced energy consumption of the process that uses the recovered heat. The energy figures we use are enthalpy values. An exergy analysis would give further insight in the potentials of heat cascading plant, such as paper mills.
The yield of a process is dependent on raw material quality (European Integrated Pollution Prevention and Control Bureau (EIPPCB) 2001). Especially in recovered paper, raw material qualities can vary considerably. Recovered paper can be collected from offices, households, retailers or other places. This results in different grades of recovered paper (e.g. office waste, mixed waste and old corrugated containers. The country and area where recovered paper is collected can also affect the raw material quality. This is mainly due to differences in collecting and sorting practices (Stawicki and Read 2010). Because of varying recovered paper quality, some mills may have to take additional efforts in the stock preparation as compared with comparable mills in different areas. In this study, we take into account differences in feedstock (i.e. virgin or recovered fibres), but we do not specify differences in raw material qualities.

\section{Approach to calculate SEC of processes}

The final energy used for paper production can be calculated back into primary energy, by multiplying the consumption of heat and electricity with standard conversion efficiencies. ${ }^{2}$ We call the primary energy use calculated as such end-use energy (Fig. 2). Enduse energy can be distinguished from site-use energy (Fig. 3). Dutch paper mills use natural gas as their primary source of energy. They have their own steam production and the majority of the mills also produce their own electricity by combined heat and power production (CHP). Therefore, primary energy consumption could also be calculated as total fuel intake plus purchased electricity and steam, diminished with electricity, steam and fuel sold (site-use energy). The difference between these two determines the efficiency of on-site energy generation of the mill as compared with standard conversion efficiency. At site level, the indicator site-use energy can be preferred over end-use energy as it takes into account the efficiency of energy conversion on site and is a good indicator for actual costs. Comparison of both siteand end-use energies gives better insights into the efficiency of on-site energy generation. To compare energy efficiencies at paper-production process level,

\footnotetext{
${ }^{2}$ We assume the following conversion factors: for electricity, $42 \%$ and for heat, $90 \%$ (LHV).
} 


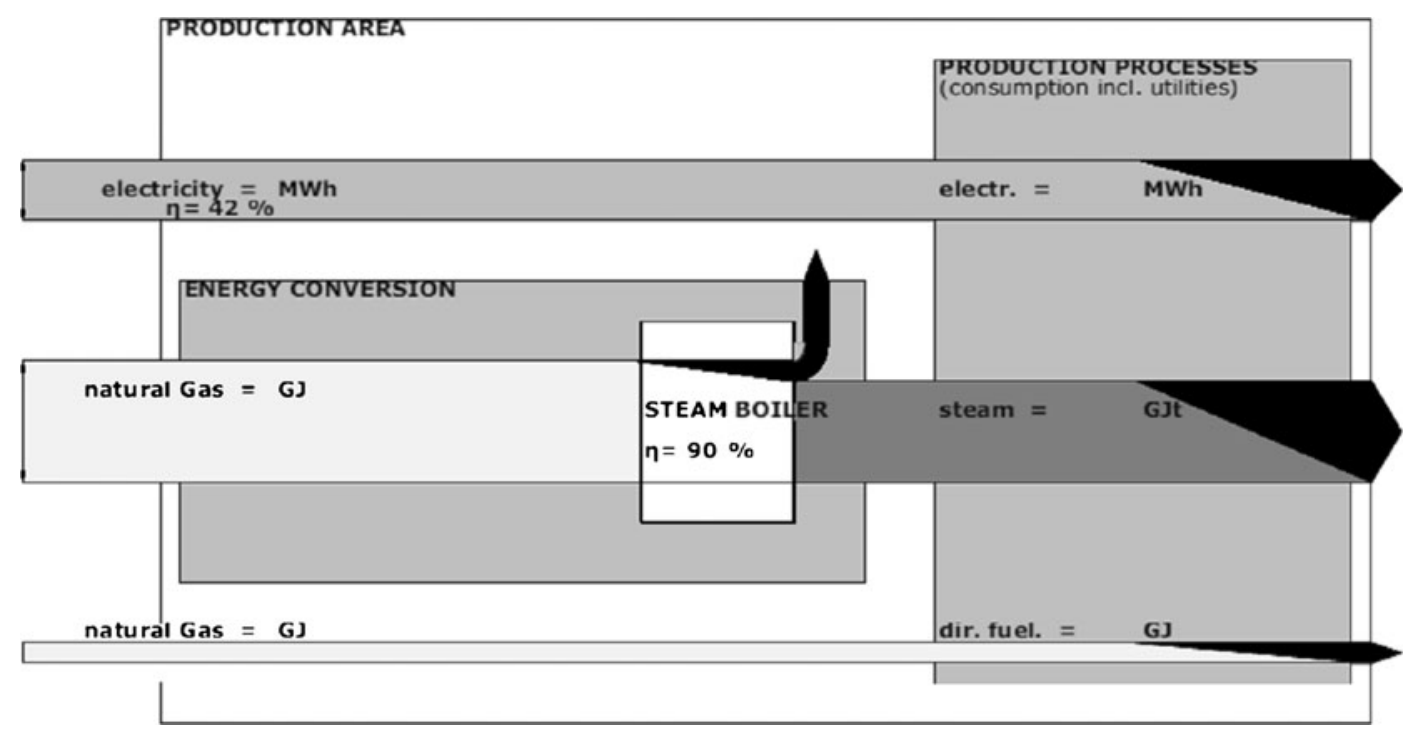

Fig. 2 Overview of end-use energy in schematic Sankeydiagram (source: VNP)

however, the efficiency of the conversion installation (e.g. CHP installation) should not play a role. Therefore, in this study, we use end-use energy (Fig. 2) and we thus exclude the efficiency gains related to for example CHP. The total annual end-use energy of a process unit is calculated with Eq. 1.

$$
E_{\text {process }}=\frac{\text { Elec }_{\text {process }} * 3.6}{\eta_{\text {elec }}}+\frac{\text { Steam }_{\text {process }}\left(\mathrm{GJ}_{\mathrm{t}}\right)}{\eta_{\text {steam }}}+\text { Fuel }_{\text {process }}
$$

Where, $E_{\text {process }}$ is the total annual end-use energy in the process (in gigajoules per year); Elec $_{\text {process }}$ is the

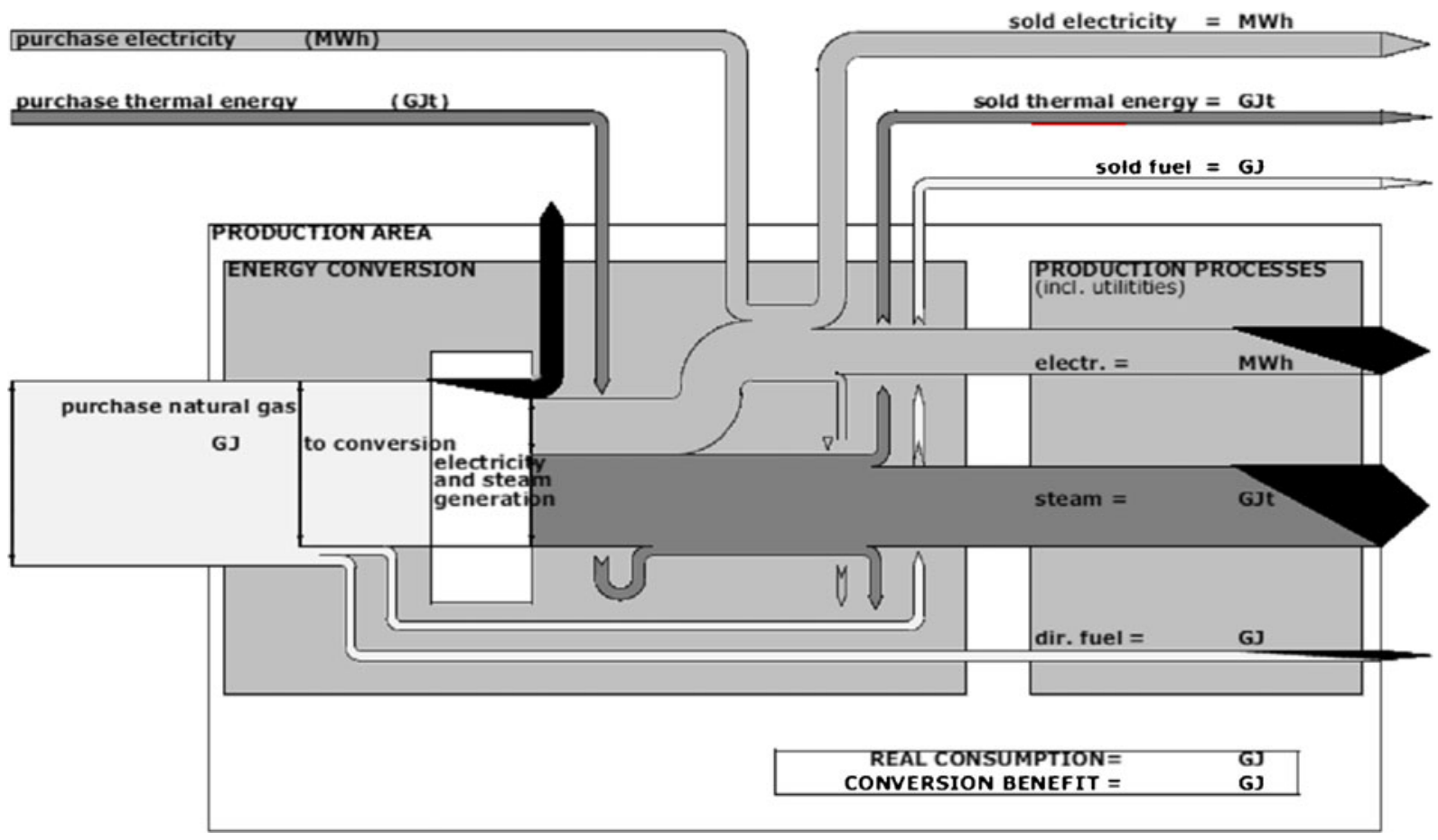

Fig. 3 Overview of site-use energy in schematic Sankeydiagram (source: VNP) 
annual process electricity consumption (in megawatt

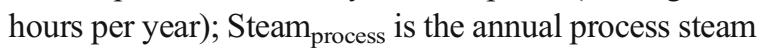
consumption (in gigajoules per year); Fuel $_{\text {process }}$ is the annual process fuel consumption (in gigajoules per year); $\eta_{\text {elec }}$ is the conversion factor for electricity into primary energy (42\%); and $\eta_{\text {steam }}$ is the conversion factor for steam into primary energy $(90 \%)$.

The specific primary energy consumption of a process unit can be calculated with Eq. 2.

$\mathrm{SEC}_{\mathrm{pr}}=\frac{E_{\text {process }}}{P}$

Where, $\mathrm{SEC}_{\mathrm{pr}}$ is the specific primary energy consumption of a process unit; $E_{\text {process }}$ is the total annual end-use energy in the process (in gigajoules per year); and $P$ is the annual amount of product that is processed in the specific process (in tons per year).

During paper production, internal waste is generated, for example when the paper web breaks or during a shift in production from one grade to another. Often, the internal waste can be pulped again internally to avoid material losses. The energy that has already been used to produce the paper, on the other hand, is lost. Equation 3 describes the total energy loss by internal waste production:

$E_{\text {waste }}=$ Waste $* \mathrm{SEC}_{\text {waste }}$

Where, $E_{\text {waste }}$ is the total energy loss by internal waste production (in gigajoules per year); Waste is the annual amount of waste (in tons per year); and $\mathrm{SEC}_{\text {waste }}$ is the specific energy use (in in gigajoules per ton) of paper production excluding the energy use during paper finishing.

\section{Methodology to analyse results}

Mills are clustered based on the dominant paper grade they produce: board (B), graphical papers $(\mathrm{G})$, tissue $(\mathrm{T})$ and other grades $(\mathrm{O})$. Mill numbers refer to the same mill throughout all graphs. All graphical mills use $100 \%$ virgin fibre as feedstock; all other mills ( $\mathrm{B}, \mathrm{T}$ and $\mathrm{O}$ ) have at least $85 \%$ of recovered fibres in their total feedstock. Input (feedstock), output (dominant grade) and process are defined as the structural indicators that influence SEC (Phylipsen et al. 1997). For each process, the average SEC per grade is calculated in order to identify the impact of structural indicators. We further calculate the ranges in SEC within each of the four identified grades. We review literature in order to identify the main aspects or explanatory indicators (Phylipsen et al. 1997) that might influence this range and that could be seen as energy improvement measures.

\section{Results and discussion}

Energy use in de-inking and dispersion

The SEC of de-inking and dispersion is shown in Fig. 4. From the 23 mills, only the tissue and other grade mills have dispersion units. Table 1 shows the average SEC and the range in SEC per paper grade. The average SEC of dispersion is with $0.4 \mathrm{GJ} / \mathrm{t}$ pulp higher in tissue production as compared with other grades. De-inking is applied in the tissue mills and in two of the other grade mills. The average de-inking SEC of tissue is $0.7 \mathrm{GJ} / \mathrm{t}$ pulp lower than the average SEC of two other grades mills (Table 1). For tissue, the ranges in SEC of the individual dispersion $(1.2 \mathrm{GJ} / \mathrm{t}$ pulp) and de-inking processes (0.9 GJ/t pulp) are high; the range becomes significantly narrower $(0.7 \mathrm{GJ} / \mathrm{t}$ pulp) if we combine the SECs of the two processes (Table 1). This could be an indication that there is a trade-off between the two.

According to Göttsching and Pakarinen (2000), the tasks of dispersion vary considerably depending on recycling fibre furnish quality and final product (structural indicators). Apart from the different tasks of dispersion, energy use also depends on stock viscosity, temperature, type of fillings and peripheral speed (Göttsching and Pakarinen 2000). The latter aspects could be considered as key parameters in order to improve the energy efficiency of this process. Selective flotation is used for removing ink particles. Energy consumption of flotation depends largely on the amount of flotation cells, which is in its turn closely related to the end product requirements (structural effect). Process related energy improvement measures in de-inking could be found in the design of piping and the types of air injectors applied (European Integrated Pollution Prevention and Control Bureau (EIPPCB) 2001).

Energy use in stock preparation

In Fig. 5, SEC of stock preparation (excluding deinking and dispersion) is shown. We can distinguish mills 
Fig. 4 SEC for de-inking and dispersion processes (in gigajoules per ton of adpp)

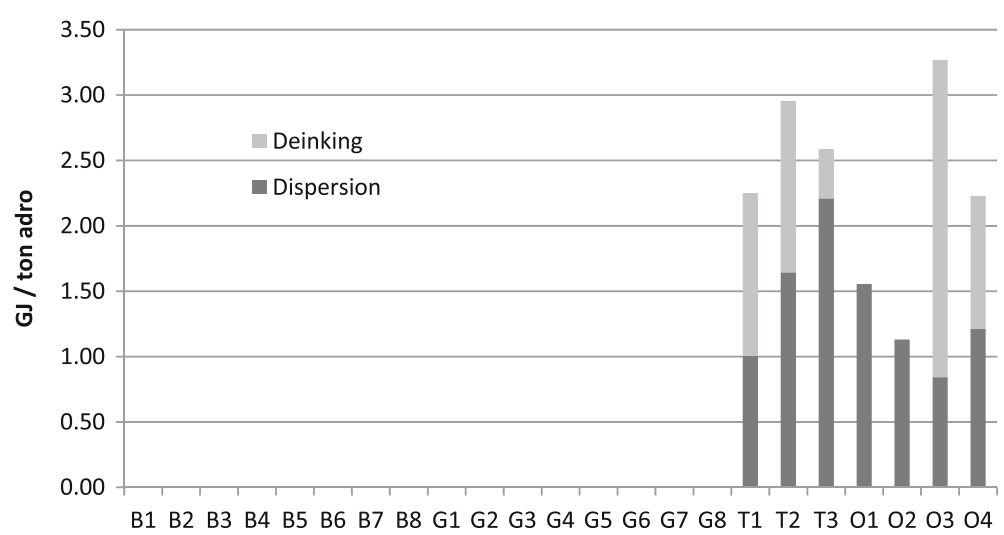

with virgin fibre input $(\mathrm{G})$ and mills with (over $85 \%$ ) recovered fibre input $(\mathrm{B}, \mathrm{T}$ and $\mathrm{O}$ ) Table 2 summarises the average SEC per grade as well as the ranges in SEC per grade. The latter can be considered an indication of the energy improvement potential. From Table 2, it can be seen that there are large difference in SEC between grades. The average SEC of stock preparation in board mills is only $0.7 \mathrm{GJ} / \mathrm{t}$ stock, whereas SEC of the same process in tissue and graphical mills is $2.3 \mathrm{GJ} / \mathrm{t}$ stock. The high SEC of stock preparation in graphical paper production can be explained by their use of refiners. Refining equipment is used in all of the graphical mills and in none of the recovered based paper mills. Unfortunately, our data do not allow for reporting the SEC of refining separately. The relatively high SEC of tissue can be explained by a relatively high fibre loss in stock preparation of tissue as well by a low consistency level of the stock.

The SEC range in stock preparation for graphical papers was found to be 1.5-3.0 GJ/t stock. As mentioned before, most of the energy in stock preparation of virgin fibres goes to refining. Refining is needed to improve the bonding ability of the individual fibres in the finished paper. The energy needed for refining is to a large extent related to quality specification of end product (European Integrated Pollution Prevention and Control Bureau (EIPPCB) 2001; Paulapuro 2000). With our data, we are not able quantify the difference between this structural effect and other energy efficiency effects. The SEC range of board mills is relatively small, but still indicates an improvement potential of $0.3 \mathrm{GJ} / \mathrm{t}$ stock for the mill with highest SEC (B4). The energy efficiency improvement potential of tissue mill $\mathrm{T} 1$ is approximately $0.6 \mathrm{GJ} / \mathrm{t}$ stock when compared with mill T3.

Energy use in forming and press section

An overview of the SEC in the combined forming and press section is shown in Fig. 6. From Table 3, it can be seen that differences in average SEC between the grades are small, indicating a limited effect of structural indicators. At the same time, the individual ranges in all grades are very high (up to a factor 6), indicating a large energy improvement potential within this process.

Table 1 Dispersion and de-inking: average specific energy consumption (SECs) and ranges in SEC for four different paper grades

\begin{tabular}{|c|c|c|c|c|c|c|}
\hline \multirow[t]{2}{*}{$\mathrm{SEC}(\mathrm{GJ} / \mathrm{t}$ pulp$)$} & \multicolumn{2}{|c|}{ Dispersion } & \multicolumn{2}{|c|}{ De-inking } & \multicolumn{2}{|c|}{ Dispersion and de-inking combined } \\
\hline & Average & Range & Average & Range & Average & Range \\
\hline Board & - & - & - & - & - & - \\
\hline Graphical & - & - & - & - & - & - \\
\hline Tissue & 1.6 & $1.0-2.2$ & 1.0 & $0.4-1.3$ & 2.6 & $2.3-3.0$ \\
\hline Other & 1.2 & $0.8-1.6$ & $1.7^{\mathrm{a}}$ & $1.0-2.4^{\mathrm{a}}$ & - & - \\
\hline
\end{tabular}

\footnotetext{
${ }^{a}$ Including only mills $\mathrm{O} 1$ and $\mathrm{O} 2$
} 
Fig. 5 Specific primary energy consumption during stock preparation, excluding TMP production, deinking and dispersion (in gigajoules per ton of adpp)

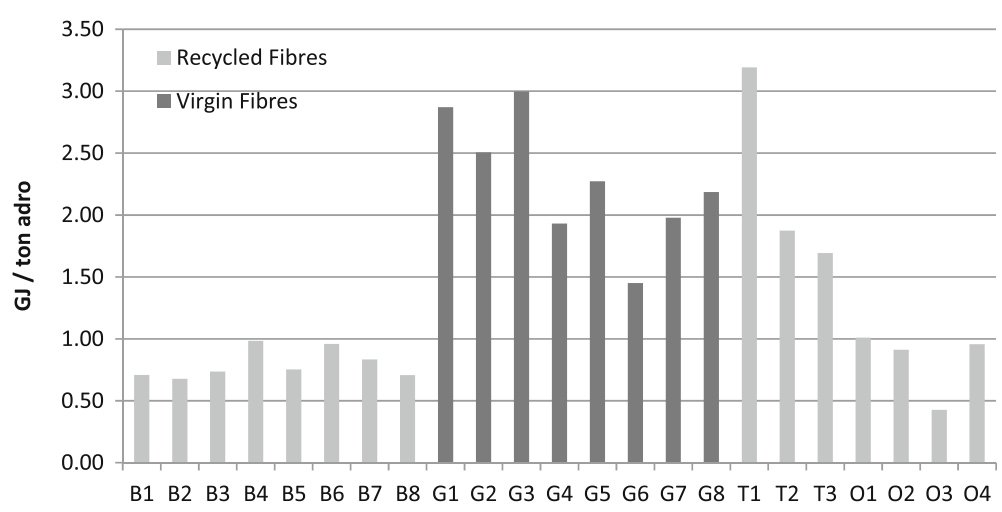

We have decomposed the specific primary energy use in electrical and thermal energy use (Fig. 6). Given the limited impact of structural effects in this process, we compare SECs of all paper grades. Figure 6 shows a large range in specific electricity use (0.3$3.0 \mathrm{GJ} / \mathrm{t}$ paper) between mills, which indicates a large energy improvement potential in this area. Differences in electricity use can be explained by differences in, e.g. pump, compressor and/or vacuum capacities and efficiencies as well as machine speed. The energy potential of optimisations in the vacuum system is considered to be large, but unfortunately this aspect has not gained too much attention in many paper mills (Paulapuro 2000). A considerable energy saving potential in this section could further be found in overdimensioned pumps and compressors (Wikström et al. 2007; Möllersten et al. 2003). Ranges in specific steam use (0.0-1.1 GJ/t paper) are somewhat smaller than ranges in specific electricity use and could be explained by, e.g. the presence/absence of steam boxes and/or differences in process water temperature levels. Increased process water temperatures are often beneficial for mills as these lead to increased production (Cutshall et al. 1988; Patterson and Iwamasa 1999).

Table 2 Stock preparation: average specific energy consumption (SECs) and ranges in SEC for four different paper grades

\begin{tabular}{lll}
\hline Stock preparation & \multicolumn{2}{l}{ SEC $(\mathrm{GJ} / \mathrm{t}$ stock $)$} \\
\cline { 2 - 3 } & Average & Range \\
\hline Board & 0.7 & $0.7-1.0$ \\
Graphical & 2.3 & $1.5-3.0$ \\
Tissue & 2.3 & $1.7-2.3$ \\
Other & 0.8 & $0.4-1.7$ \\
\hline
\end{tabular}

As compared with the other grades, board mills have a relatively high thermal energy use in this section (Fig. 6). Board mills do not use refiners or dispersion units, which both increase process temperatures. Therefore, their thermal energy demand might be higher than that of others in this section. Some mills use steam for process water heating (Breedveld et al. 1998), whereas heat could also be gained via heat recovery from the drying section. Such a measure would considerable improve energy efficiency in these types of mills (Laurijssen et al. 2010).

\section{Energy use in drying section}

Figure 7 shows the SEC in the pre- and after dryer sections of the 23 paper and board mills. Here, values are expressed per ton of absolute dry end product (adep) and not per ton of absolute dry processed product (adpp). This is because the results of both dryers are combined and there are mass differences due to differences in material losses and additives (coatings, paper and starch). Mill G8 has an unrealistically low SEC in the pre-dryer and a very high SEC in the after-drying section. We assume that the SEC figures for this mill are not correct, and we have excluded these figures from the results in Table 4.

Table 4 shows that the differences in average SEC between grades are large. The average SEC of the drying process in board mills is only $4.8 \mathrm{GJ} / \mathrm{t}$ paper, whereas the SECs of the same process in tissue and graphical mills are 7.0 and $7.6 \mathrm{GJ} / \mathrm{t}$ paper, respectively. From Fig. 7, it can be seen that the high SEC of graphical grades is largely due to a high SEC in the after dryer, which is caused by relatively large water additions in the coating process of graphical papers. The SEC ranges within the four grades indicate 
Fig. 6 Specific primary energy consumption, decomposed in electrical and thermal energy use, in the combined forming and press section (in gigajoules per ton of adpp)

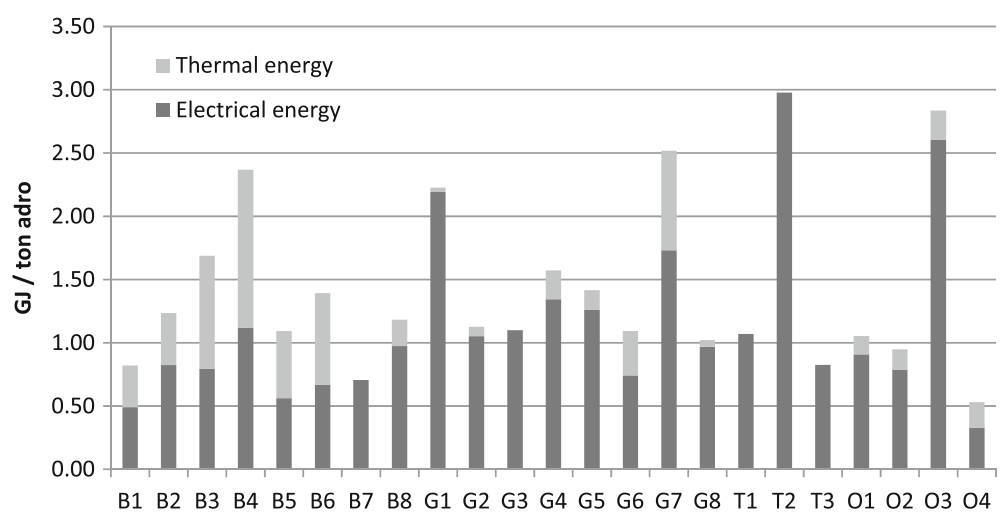

considerable energy efficiency improvement potentials for all grades. In order to gain more insight in this improvement potential, we reduce the influence of an important structural indicator: amount of water removal. To do so, we split SEC of drying into the amount of water removal per ton of paper production (Fig. 8) and the energy use per ton water evaporation (=dryer efficiency) (Fig. 9).

The amount of water removal (Fig. 8) varies from 0.9 to $2.0 \mathrm{t}$ water/t paper. Water removal depends on, e.g. dry matter content after the press, water additions in between the drying sections, paper weight and moisture content of the end-product. Most of these aspects largely depend on product (quality) requirements and are considered to be structural effects.

Figure 9 shows that the energy use per ton of water evaporation is less product specific. Only the energy use in the tissue mills is slightly higher as compared with the other grades. A reason for this could be found in the different type of dryer that used in tissue production (Yankee) as compared with the other grades (multi-cylinder dryers). Energy use in Yankee dryers is in most cases slightly higher than in multi-cylinder

Table 3 Forming and press section: average specific energy consumption (SECs) and ranges in SEC for four different paper grades

\begin{tabular}{lcc}
\hline Forming and press & \multicolumn{2}{l}{$\operatorname{SEC}(\mathrm{GJ} / \mathrm{t}$ paper $)$} \\
\cline { 2 - 3 } & Average & Range \\
\hline Board & 1.3 & $0.7-2.4$ \\
Graphical & 1.5 & $1.0-2.5$ \\
Tissue & 1.6 & $0.8-3.0$ \\
Other & 1.3 & $0.5-2.8$ \\
\hline
\end{tabular}

dryers (Karlsson 2000). In general, the range in drying energy between all mills (3.6-6.2 GJ/t water removal) indicates a large energy-efficiency improvement potential. The main aspects that can influence dryer efficiency are dryer section closure (open, partly open or closed hood), the dryer dew point and the presence or absence of a heat recovery system. Energy efficiency is highest when the dryer is fully closed, the dryer dew point is high and heat is maximally recovered (Laurijssen et al. 2010).

Total primary energy intensity

In Fig. 10, the total primary energy intensity per ton of final paper production, broken down in different processes, is shown for the 23 mills analysed in this study. Also, the total energy loss due to internal waste production (see 'Methodology') is indicated in this figure. The absolute energy loss due to internal waste production is highest for the graphical grades $(2.4 \mathrm{GJ} / \mathrm{t}$ paper on average) and lowest for the other grades (1.0 GJ/t paper). The share of waste related energy losses, as compared with the total energy use, varies largely from 2 (B4) to $33 \%$ (G4). Waste-related energy losses can be caused by differences in general operational efficiency of the paper machine but also by frequent shifts from one grade to another within a certain paper mill.

The total primary energy intensity is largely dependent on the grade produced, as can be seen from Fig. 10. In Table 5, for each of the four defined grades, the average SEC per process (in this case based on the amount of final product produced, not on the amount of product processed in the respective unit operation as done before) and the total average SEC per grade are calculated. Table 5 shows that energy use in the 
Fig. 7 Specific primary energy consumption in preand after drying section (in gigajoules per ton of adep)

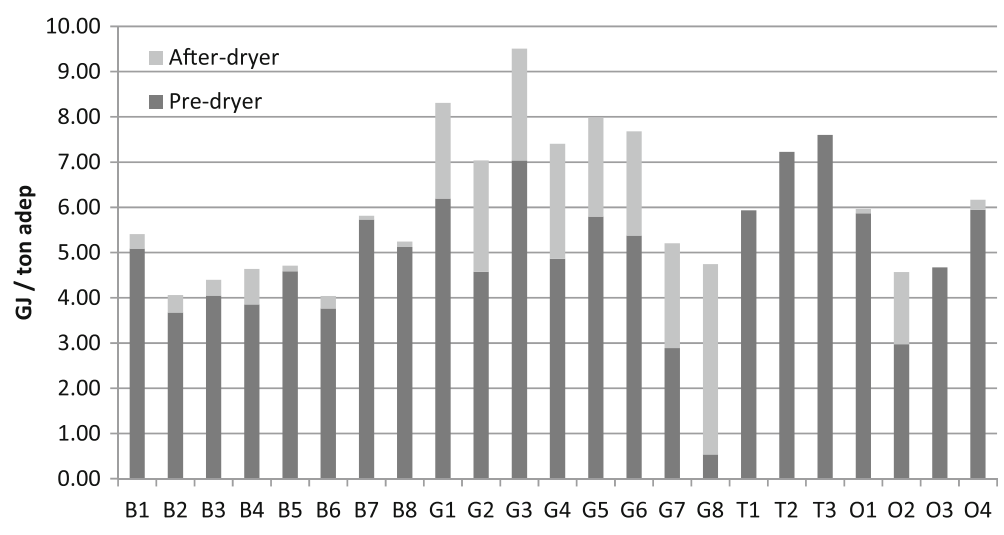

pre-dryer section is the process unit with the highest specific energy use in all grades. The share of drying energy (pre- and after drying sections combined) in the total SEC, varies from $47 \%$ for tissue production to $64 \%$ in board production. SEC in stock preparation processes is highest in tissue production $(5.6 \mathrm{GJ} / \mathrm{t}$ stock) and lowest in board production (1.0 GJ/t stock). Average-specific energy use in the wire and press section is most comparable for all paper grades, although the individual differences between mills can be large (as we have seen in Fig. 6).

\section{Discussion}

Data used in this study were collected by the mills themselves. More than 200 data points were provided by every single mill, which makes this industrial data collection effort unique in itself. Data are based on mills' annual averages, meaning that data were not available for every single type of product produced in every different mill, although this level of detail would be preferred. The available dataset does,

Table 4 Drying sections: average specific energy consumption (SECs) and ranges in SEC for four different paper grades

\begin{tabular}{llr}
\hline Drying sections & \multicolumn{2}{l}{ SEC (GJ/t paper) } \\
\cline { 2 - 3 } & Average & \multicolumn{1}{c}{ Range } \\
\hline Board & 4.8 & $4.0-5.8$ \\
Graphical & $7.6^{*}$ & $5.2 *-9.5$ \\
Tissue & 7.0 & $6.0-7.6$ \\
Other & 5.3 & $4.6-6.2$ \\
\hline
\end{tabular}

*Excluding mill G8 unfortunately, not allow a quantified uncertainty analysis in terms of measurement errors. All mills have used their own measuring devices, but the process of data collection has been guided by a single expert for all mills. Moreover, a uniform format for data management (MPI-PEMS) was used by all mills and the same system and process boundaries were therefore used throughout the sector. We therefore consider the data to be reliable and representative. Two Dutch paper mills were excluded from the analysis. In reality, the ranges in energy usage in the Dutch Paper and Board industry would therefore be larger. With the described method, it should be possible to perform a similar analysis in another country or in another industrial sector. For such an analysis, participation of the industry seems crucial because the required level of data is mostly not available in public data sources and/or statistics.

Besides their use in scientific studies, energy efficiency indictors and benchmarks are also found in policy making. Several policies in place today rely on measures of energy efficiency performance, primarily to evaluate regulatory performance (Tanaka 2008). Given the number and the complexity of industrial processes and product end-uses, designing consistent and comparable efficiency indices for use in policy-making/implementation processes is extremely difficult (Tanaka 2008). Gielen and Taylor (2009) add that taking account of different product categories is of key importance as various products in a single category may require considerably different amounts of energy for their production. This is confirmed by the results from our study. From a policymaking point of view, the results of our study support the view that there is a need for better quality industrial data, especially when benchmarks are to be used 
Fig. 8 Water removal in the drying section per ton of absolute dry end product (in gigajoules per ton of adep)

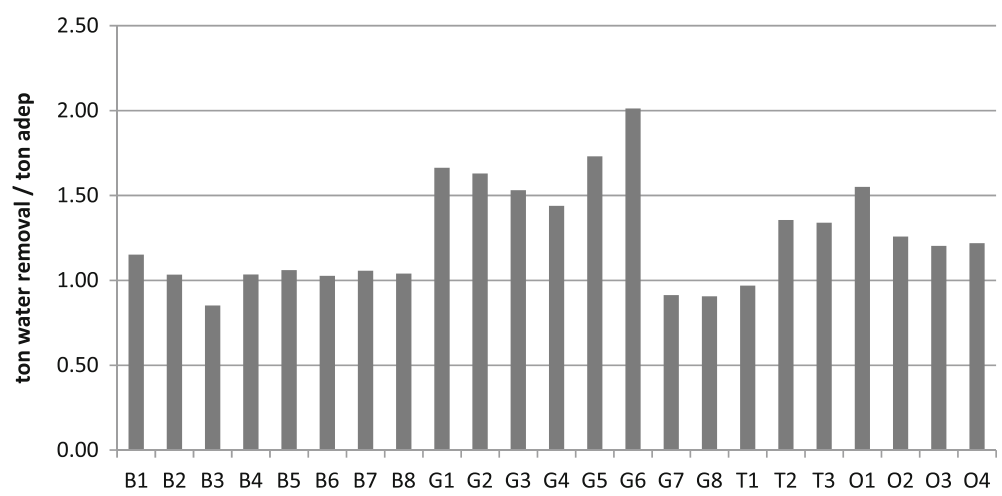

in industrial target settings. However, even when data on a detailed level would be available, knowledge of and insight in the specific production processes is needed in order to identify realistic improvement potentials at mill level, if that is the goal of the benchmark.

Looking at our results, we found that even a benchmark on the detailed process unit level, in most cases does not lead to realistic estimations of energy improvement potentials (defined as measures that can be taken at mill/process level) without accounting for structural effects (e.g. inputs and outputs). However, when different product grades and processing routes are taken into account, estimations of energy improvement potentials could, in some cases, be made. Moreover, an energy benchmark on process unit level provides a good insight into the level of variation in energy use between different mills producing similar grades. A limitation of benchmarking on process unit level is that, with a focus on individual processes, an overview on the efficiency of the total process is lost. Sometimes, higher energy intensity in a specific unit operation is needed to enable an energy saving in the total production process. Also, energy losses related to internal waste generation are not taken into account when analysing energy use on process level only. Our results show that the impact of waste related energy use can be considerable. It is therefore recommended to look at the whole process and use sub-processes as diagnostics to locate problems or to identify energy saving opportunities for processes with comparable inputs and outputs.

\section{Conclusions}

The aim of this study has been to benchmark the SEC of similar processes within different paper mills in order to identify energy improvement potentials at process level. We defined improvement potentials as measures that can be taken at mill/process level under assumed fixed inputs and outputs. We have used a benchmarking method based on energy and material balances per process, and we were able to use industrial data on detailed process level.
Fig. 9 Energy use (in GJ per ton of water removal) in the drying section

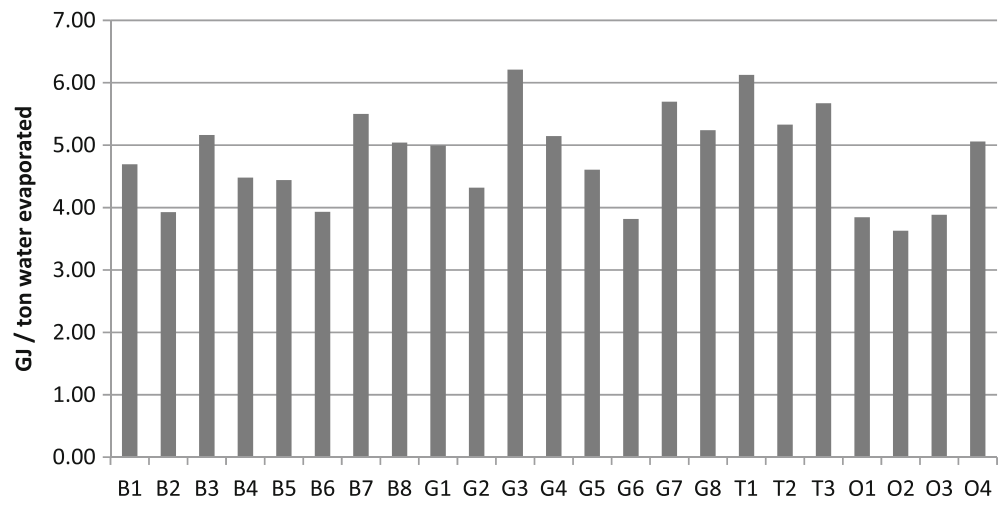


Fig. 10 Breakdown of total primary energy intensity per process, including total energy loss due to internal waste production (in gigajoules per ton of adep)

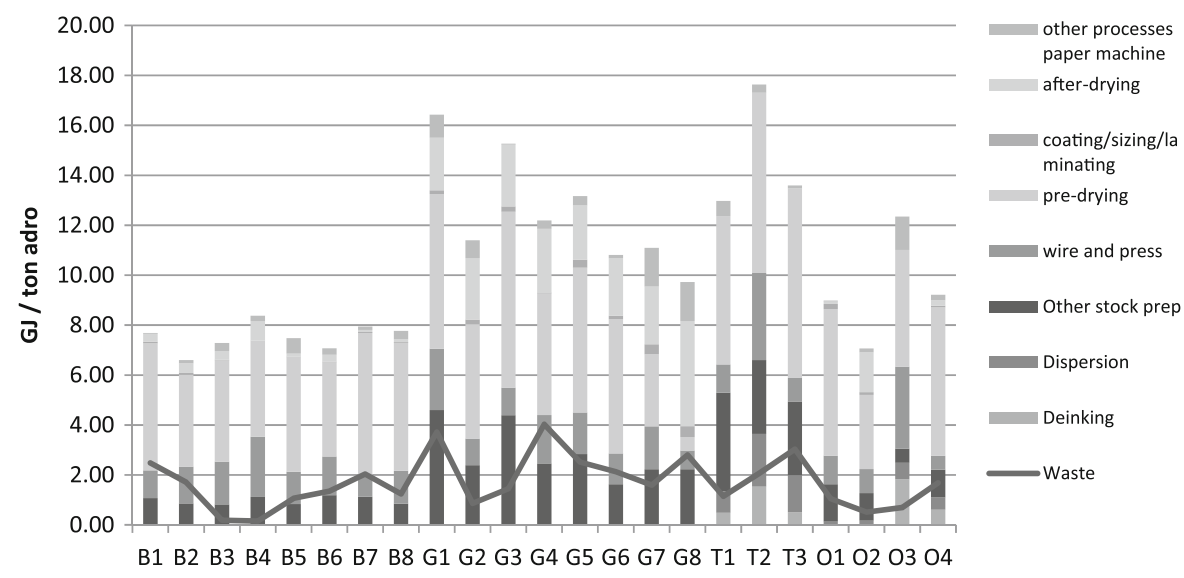

The energy efficiency improvement potential, calculated as the gap between the lowest and highest value, in the combined de-inking and dispersion processes was found to be $0.7 \mathrm{GJ} / \mathrm{t}$ pulp for the least efficient tissue mill. In stock preparation (excluding de-inking and dispersion), the improvement potential was found to be low for board mills $(0.3 \mathrm{GJ} / \mathrm{t}$ stock) and tissue (0.6 GJ/t stock). The highest range in SEC was found in graphical grades (1.5-3.0 GJ/t paper), although this range is not an indication for an improvement potential per se, given the large contribution of refining to the energy use in this section and the fact that refining energy largely influences product specifications. The large range in SEC in the forming and press section (0.5-3.0 GJ/t paper) together with the fact that the average SEC in this section was found to be comparable between grades (1.3-1.6 GJ/t paper) indicates a significant energy efficiency improvement potential in this section. We found that water removal in the drying section is rather grade specific, while differences in energy consumption for evaporation indicate significant improvement potentials in the drying section (up to $2.6 \mathrm{GJ} / \mathrm{t}$ water removed).
Despite the detailed data we were able to use in this study, it is still delicate to draw some firm conclusions on the available energy efficiency potential in the Dutch paper and board industry. On a more general level, we can state that there are significant opportunities for energy efficiency improvement in the wire and press section as well as in the drying section. The total energy improvement potential based on identified best practices in these sections is estimated at $5.4 \mathrm{PJ}$ (or $15 \%$ of the total primary energy use in the selected mills). Energy efficiency improvement potentials can also be found in stock preparation, de-inking and dispersion, but we consider energy use in these processes too dependent on quality issues and product specifications to quantify this.

There are various measures of industrial energy efficiency performance, with different purposes and applications. The results of this study have contributed to the discussion of the roles, advantages and risks of some of these measures. This paper emphasises the importance of a decent understanding of the underlying principles in assessing energy efficiency

Table 5 Average specific energy consumption (SEC) per process in GJ/t paper (adep) for four different paper grades

\begin{tabular}{lccccccccc}
\hline & $\begin{array}{l}\text { De-inking } \\
(\mathrm{GJ} / \mathrm{t})\end{array}$ & $\begin{array}{l}\text { Dispersion } \\
(\mathrm{GJ} / \mathrm{t})\end{array}$ & $\begin{array}{l}\text { Other stock } \\
\text { prep }(\mathrm{GJ} / \mathrm{t})\end{array}$ & $\begin{array}{l}\text { Wire and } \\
\text { press }(\mathrm{GJ} / \mathrm{t})\end{array}$ & $\begin{array}{l}\text { Pre-drying } \\
(\mathrm{GJ} / \mathrm{t})\end{array}$ & $\begin{array}{l}\text { Coating/sizing/ } \\
\text { laminating } \\
(\mathrm{GJ} / \mathrm{t})\end{array}$ & $\begin{array}{l}\text { After-drying } \\
(\mathrm{GJ} / \mathrm{t})\end{array}$ & $\begin{array}{l}\text { Other processes } \\
\text { paper machine } \\
(\mathrm{GJ} / \mathrm{t})\end{array}$ \\
\hline Board & 0.0 & 0.0 & 1.0 & 1.5 & 4.5 & 0.0 & 0.3 & 0.3 \\
Graphical & 0.0 & 0.0 & 2.8 & 1.5 & 4.7 & 0.2 & 2.6 & 0.7 \\
Tissue & 0.8 & 1.5 & 3.3 & 1.9 & 6.9 & 0.0 & 0.0 & 0.3 \\
Other & 0.6 & 0.4 & 1.1 & 1.5 & 4.9 & 0.1 & 0.5 & 0.3 \\
\hline
\end{tabular}


and in comparing different mills within a benchmark. Given the expressed need for better industrial data, especially in paper production, this paper further contributes to increased data availability of industrial process data.

Acknowledgements We thank The Royal Netherlands' Paper and Board Association and its members for being able to use their data and F. J. de Gram for his efforts to make monitoring within the Dutch paper industry possible. Without them this study would not have been possible.

Open Access This article is distributed under the terms of the Creative Commons Attribution License which permits any use, distribution, and reproduction in any medium, provided the original author(s) and the source are credited.

\section{References}

Breedveld, L., Luttmer, W. \& Senhorst, H. (1998). Towards water system closure in the paper industry, Hand-out for the TWG-Pulp \& paper, 25 November 1998, Seville.

Confederation of European Paper Industries (CEPI) (2007). Energy issue sheet. Energy markets, the need for fully liberalised and well-functioning markets in Europe. http:// www.cepi.org/Objects/1/Files/070129IssueEnergy.pdf. Accessed 05 August 2008.

Confederation of European Paper Industries (CEPI) (2008). Energy. http://www.cepi.org/Content/Default.asp? PageID=54. Accessed 05 August 2008.

Cutshall, K., Bell, N. \& Hudspet, D. (1988). Hot pressing. In: Proceedings of TAPPI, practical aspects of pressing and drying seminar, Atlanta, Georgia, 14-18 March 1988.

De Beer, J., Worrell, E., \& Blok, K. (1997). Long-term energyefficiency improvements in the paper and board industry. Energy, 23, 21-42.

Eichhammer, W., \& Mannsbart, W. (1997). Industrial energy efficiency - indicators for a European cross-country comparison of energy efficiency in the manufacturing industry. Energy Policy, 25, 759-772.

European Integrated Pollution Prevention and Control Bureau (EIPPCB) (2001). Reference Document on Best Available Techniques in the Pulp and Paper Industries. Adopted by the European Commission in December 2001. www.eippcb.jrc.es. Accessed 20 Oct 2009.

Farla, J. C. M., \& Blok, K. (2000). The use of physical indicators for the monitoring of energy intensity developments in the Netherlands, 1980-1995. Energy, 25, 609-638.

Farla, J., Blok, K., \& Schipper, L. (1997). Energy efficiency developments in the pulp and paper industry. Energy Policy, 25, 745-758.

Francis, D.W., Towers, M. \& Browne, T. (2006) Benchmarking energy use in pulp and paper operations. In 92nd Annual Meeting of the Pulp and Paper Technical Association of Canada, Montreal, QC, Canada, 7-9 Feb 2006, Book A, pp $55-62$
Freeman, S. J., Niefer, M. J., \& Roop, J. M. (1997). Measuring industrial energy efficiency: practical issues and problems. Energy Policy, 25, 803-812.

Gielen, D., \& Taylor, P. (2009). Indicators for industrial energy efficiency in India. Energy, 34, 962-969.

Göttsching, L. \& Pakarinen, H. (eds) (2000). Recycled fiber and deinking. In Papermaking Science and Technology, Book 7. Helsinki, Finland: Fapet Oy/Finnish Paper Engineers Association/TAPPI.

International Energy Agency (IEA) (2008). Worldwide trends in energy use and efficiency - key insights from IEA Indicator Analysis, 2008.

Karlsson, M. (eds.) (2000) Papermaking Part 2: drying. In Papermaking science and technology, Book 9. Helsinki, Finland: Helsinki, Finland: Fapet Oy/Finnish Paper Engineers Association/TAPPI

Laurijssen, J., De Gram, F. J., Worrell, E., \& Faaij, A. P. C. (2010). Optimizing the energy efficiency of conventional multi-cylinder dryers in the paper industry. Energy, 35, 3738-3750.

Lazarus, M., Kartha, S., Bernow, M., \& Dunmire, C. (1999). Clean development mechanism baselines: an evaluation of the benchmarking approach. Boston: Tellus Institute.

Möllersten, K., Yan, J., \& Westermark, M. (2003). Potential and cost-effectiveness of $\mathrm{CO}_{2}$ reductions through energy measures in Swedish pulp and paper mills. Energy, 28, 691-710.

Neelis, M., Ramirez-Ramirez, A., Patel, M., Farla, J., Boonekamp, P., \& Blok, K. (2007). Energy efficiency developments in the Dutch intensive manufacturing industry, 1980-2003. Energy Policy, 35, 6112-6131.

Patterson, M. G. (1998). What is energy efficiency? Concepts, indicators and methodological issues. Energy Policy, 24, 377-390.

Patterson, T.F. \& Iwamasa, J.M. (1999). Review of web heating and web pressing literature. In TAPPI Papermakers Conference Proceedings, TAPPI PRESS, Atlanta, pp 12551278.

Paulapuro, H. (eds.) (2000). Papermaking Part 1: stock preparation and wet end. In Papermaking Science and Technology Series, Book 8. Helsinki, Finland: Fapet Oy/Finnish Paper Engineers Association/TAPPI

Phylipsen, G. J. M., Blok, K., \& Worrell, E. (1997). International comparisons of energy-efficiency-methologies for the manufacturing industry. Energy Policy, 25, 715-725.

Rafiqul, I., Weber, C., Lehmann, B., \& Voss, A. (2005). Energy efficiency improvements in ammonia production-perspectives and uncertainties. Energy, 30, 2487-2502.

Ramirez, C. A., Blok, K., Neelis, M., \& Patel, M. (2005). Adding apples to oranges: the monitoring of energy efficiency of the Dutch food industry. Energy Policy, 34, 1720-1735.

Ruth, M., Worrell, E. \& Price, L. (2001). A process-step benchmarking approach to energy use at industrial facilities: examples from the iron and steel and cement industries. Presented at the 2001 ACEEE summer study on energy efficiency in industry.

Salta, M., Polatidis, H., \& Haralambopoulos, D. (2009). Energy use in the Greek manufacturing sector: a methodological framework based on physical indicators with aggregation and decomposition analysis. Energy, 34, 90-111. 
Stawicki, B. \& Read, B. (eds) (2010). The future of paper recycling in Europe: opportunities and limitations. Final report of COST Action E48. Bury, UK: The Paper Industry Technical Association (PITA), p 202.

Tanaka, K. (2008). Assessment of energy efficiency performance measures in industry and their application for policy. Energy Policy, 36, 2887-2902.
Vereniging van Nederlandse Papier- en kartonfabrieken (VNP). (2010). Annual Report 2009. Hoofddorp: VNP.

Wikström, P., Tolvananen, J., Savolainen, A., \& Barbosa, P. (2007). Saving energy through drive efficiency. ABB Review, 2, 73-80.

Worrell, E., Cuelenaere, R. F. A., Blok, K., \& Turkenburg, W. C. (1994). Energy consumption by industrial processes in the European Union. Energy, 19, 113-1129. 